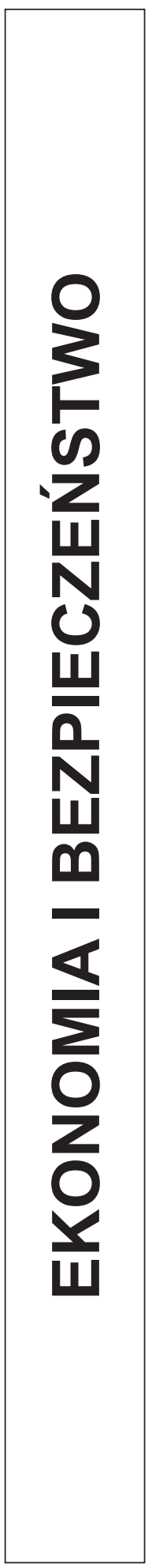





\title{
ZWIĄZKI POLITYKI I EKONOMII W BADANIU STOSUNKÓW MIĘDZYNARODOWYCH
}

\author{
MIĘDZYNARODOWA EKONOMIA POLITYCZNA \\ - DEFINICJE I ZAKRES BADAŃ
}

Związki między gospodarką i polityką są trwałym elementem stosunków międzynarodowych. Jednak w badaniach naukowych istniał podział między politologią i ekonomią, który doprowadził do specjalizacji na uniwersytetach. Osobno badano i nauczano międzynarodowych stosunków politycznych i międzynarodowych stosunków gospodarczych. Takie podejście dominowało w latach pięćdziesiątych i sześćdziesiątych XX wieku. Mniej uwagi poświęcano politycznej analizie kwestii gospodarczych. Skupiano się raczej na strategicznych, politycznych i militarnych aspektach zimnej wojny ${ }^{1}$.

$\mathrm{Na}$ początku lat siedemdziesiątych XX wieku, wyraźnie ujawniła się interakcja między polityką a gospodarką. Spadło wtedy napięcie związane z zagrożeniem wybuchem światowego konfliktu militarnego, ze względu na politykę odprężenia w relacjach między Wschodem a Zachodem. Ważnym wydarzeniem z początku tego okresu było odejście od systemu monetarnego ustalonego w 1944 r. w Bretton Woods, wymuszone przez światowy kryzys walutowy. Do uwypuklenia współzależności między polityką a gospodarką przyczynił się również kryzys naftowy 1973 r., spowodowany decyzją państw OPEC o ograniczeniu produkcji ropy naftowej i nałożeniu embarga na dostawy tego surowca do Stanów Zjednoczonych i Holandii.

Bardzo istotnym zjawiskiem była również zmieniająca się pozycja Stanów Zjednoczonych. Państwo to przeżywało wewnętrzne trudności gospodarcze, borykając się ze wzrastającą inflacją i bezrobociem. Zmagało się też z deficytem bilansu płatniczego. Jednocześnie wzrastała siła ekonomiczna Europejskiej Wspólnoty Gospodarczej i Japonii. Ożywiły się także kontakty z blokiem komunistycznym i z ChRL, która wychodziła z izolacji na arenie międzynarodowej. Wzrastała rola tzw. trzeciego świata - można było tam zauważyć rywalizację mocarstw o wpływy polityczne i gospodarcze. Poza tym kraje bogate w ropę naftową zdobywały coraz większy wpływ na stosunki międzynarodowe ${ }^{2}$.

1 Wprawdzie pojawiały się prace uwzględniające takie współzależności, ale takie podejście było rzadkie. Jako przykład można wymienić pracę Alberta Hirschmana dotyczącą wykorzystywania przez Niemcy handlu międzynarodowego do rozszerzania wpływów w Europie Środkowej (A. Hirschman, National Power and the Structure of Foreign Trade, Berkeley 1945) czy prace Charlesa Kindlebergera (np. Ch. Kindleberger, Foreign Trade and National Economy, New Haven 1962). Zob. więcej przykładów: P. Katzenstein, R. Keohane, S. Krasner, International Organization and the Study of World Politics, ,International Organization”, Autumn 1998, s. 3-36.

2 J. E. Spero, The Politics of International Economic Relations, New York 1999, s. 3-4. 
Umiędzynarodowienie systemu gospodarczego niosło ze sobą pozytywne skutki, takie jak większa efektywność, specjalizacja i konkurencja. Natomiast rządzący państwami narodowymi musieli liczyć się z poważnymi ograniczeniami. Zwiększyła się bowiem podatność krajowych gospodarek na wydarzenia za granica, na które rządy nie miały wpływu. Rodziło to konflikty przenoszące się na sferę międzynarodowych stosunków politycznych. Nieporozumienia wynikały głównie z rywalizacji o zagraniczne rynki, warunki wzajemnego handlu i inwestycji oraz kwestie monetarne ${ }^{3}$. Kluczowe znaczenie odegrała rosnąca świadomość obywateli państw demokratycznych na temat związków polityki i gospodarki. Przedmiotem debaty publicznej stały się polityczne przyczyny trudności gospodarczych oraz ekonomiczne przesłanki działania państw lub grup interesów na arenie międzynarodowej. Zauważano „upolitycznienie” zagranicznych relacji gospodarczych i rosnące wpływy interesów ekonomicznych na politykę państw ${ }^{4}$. Proste podziały między państwem a rynkiem, sprawami wewnętrznymi i zagranicznymi, polityką i gospodarką nie tłumaczyły skomplikowanych procesów. Badanie stosunków międzynarodowych wymagało kompleksowego podejścia.

W pierwszej połowie lat siedemdziesiątych XX wieku amerykańscy i brytyjscy naukowcy (m.in. Richard Cooper, Susan Strange, Robert Keohane, Joseph Nye) zauważyli, że większość opracowań na temat stosunków międzynarodowych była niekompletna ${ }^{5}$. Twierdzili, że międzynarodowa polityka gospodarcza zaczęła odgrywać kluczową rolę w kształtowaniu relacji między państwami. Zauważono, że na arenie międzynarodowej państwo działa nie tylko w sferze politycznej i wojskowej, ale również jest aktywnym aktorem w stosunkach gospodarczych. Doceniono wagę zagrożenia jego bezpieczeństwa ekonomicznego, dlatego dodano ważne kryterium siły państwa: potencjał gospodarczy ${ }^{6}$. Pojawiały się również prace przedstawiające poszczególne problemy, zakładające zdecydowaną dominację jednego z czynników: gospodarczego lub politycznego. Takie podejście krytykowali R. Keohane i J. Nye w artykule przygotowanym wspólnie z Fredem Bergstenem wykazując, że „ani polityczny, ani ekonomiczny determinizm nie wytłumaczy zjawisk wyczerpująco"7. Zauważyli, że często trudno nawet określić, czy jakieś działanie ma charakter polityczny czy gospodarczy.

Richard Cooper w pracy opublikowanej 1968 r., zwrócił uwagę na coraz większą współzależność gospodarczą państw, postulując zorganizowanie ścisłej współpracy dla

${ }^{3}$ G. M. Meier, International Economics. The Theory of Policy, New York 1980, s. 3. Por.: D. Baldwin, International Political Economy and International Monetary System, „International Organization", Autumn 1980, s. 512.

4 R. Gilpin, The Political Economy of International Relations, Princeton 1987, s. 4.

5 C. Chavagneux, Economics and Politics: Some Bad Reasons for a Divorce, „Review of International Political Economy”, Winter 2001, s. 609-632.

${ }_{6}$ E. Haliżak, Międzynarodowe stosunki ekonomiczne, w: Stosunki międzynarodowe. Geneza, struktura, dynamika, red. E. Haliżak, R. Kuźniar, Warszawa 2006, s. 202.

7 R. Keohane, J. Nye, Power and Interdependence. World Politics in Transition, Boston 1977, s. 85. Zbigniew Landau zwrócił uwagę, że równie absurdalne są próby udowodnienia rozdzielności sfer gospodarczej i politycznej, jak i szukanie za wszelką cenę motywów gospodarczych dla każdego wydarzenia politycznego, a politycznych - dla wszystkich działań gospodarczych. Patrz: Z. Landau, Zwiazki gospodarki z polityka, w: Nauki ekonomiczno-społeczne i rozwój, red. K. Żukrowska, Warszawa 2008, s. 264. 
dobra całego systemu ${ }^{8}$. Z kolei Susan Strange zakwestionowała realistyczną teorię o motywach działań państw narodowych. Wskazywała na zanik znaczenia bilateralnych relacji i wzrost multilateralizmu. Zwracała uwagę na innych aktorów stosunków międzynarodowych. Pisała, że jeśli badacze nie będą uwzględniali czynnika ekonomicznego, prace dotyczące polityki zagranicznej, studiów strategicznych i organizacji międzynarodowych nie będą oddawały rzeczywistego stanu rzeczy ${ }^{9}$. Robert Keohane i Joseph Nye sugerowali, by stosunki międzynarodowe analizować trzystopniowo: na poziomie poszczególnych obszarów (politycznym, ekonomicznym, bezpieczeństwa), uwzględniać wpływ czynników pozarządowych i transnarodowych oraz ukazywać związki między różnymi obszarami ${ }^{10}$.

Pionierskie prace tych autorów dały początek wyodrębnieniu się subdyscypliny w stosunkach międzynarodowych - międzynarodowej ekonomii politycznej - MEP (ang. International Political Economy). Nazwa ta została wprowadzona po raz pierwszy przez Susan Strange dopiero w latach osiemdziesiątych XX wieku ${ }^{11}$. W polskiej literaturze przedmiotu spotyka się określenie ekonomia polityczna stosunków międzynarodowych - EPSM (ang. Political Economy of International Relations) ${ }^{12}$, zaczerpnięte bezpośrednio z tytułu pracy Roberta Gilpina ${ }^{13}$. Jednak także R. Gilpin używa nazwy International Political Economy jako nazwy tej subdyscypliny, która do czasów współczesnych jest przyjęta w opracowaniach anglojęzycznych. Dlatego dla potrzeb tego artykułu stosowane będzie określenie „międzynarodowa ekonomia polityczna”.

MEP to nauka zajmująca się problemami międzynarodowymi, których nie można wytłumaczyć, analizując oddzielnie różne ich aspekty ${ }^{14}$. Susan Strange zdefiniowała ją jako dyscyplinę dotyczącą ,społecznych, politycznych i ekonomicznych układów, mających wpływ na światowy system produkcji, wymiany, dystrybucji i różnorodnych wartości występujących w ich obrębie" ${ }^{\text {"15 }}$.

Helen Milner wyróżniła dwie definicje. Pierwsza, bardziej ogólna, określa MEP jako ,wszystkie badania stosunków międzynarodowych oprócz badań nad bezpieczeństwem" ". Jednak określenie to wydaje się dość nieprecyzyjne, gdyż w badaniach nad

${ }^{8}$ R. Cooper, The Economics of Interdependence: Economic Policy in the Atlantic Community, New York 1968.

9 S. Strange, International Economics and International Relations: A Case of Mutual Neglect, „International Affairs”, April 1970, s. 309.

10 Transnational Relations and the World Politics, eds. R. Keohane, J. Nye Jr, Boston 1972 , s. 337-344. Zob. także: R. Keohane, J. Nye, Power and Interdependence, op. cit., s. 85.

${ }_{11}$ S. Strange, States and Markets. An Introduction to the International Political Economy, New York 1988. Na temat określeń tej subdyscypliny zob: E. Haliżak, Ujęcie roli państwa w ekonomii politycznej stosunków międzynarodowych, w: Państwo w teorii i praktyce stosunków międzynarodowych, red. M. Sułek, J. Symonides, Warszawa 2009, s. 24.

${ }^{12}$ E. Haliżak, Wspótzależność polityki i ekonomii w stosunkach międzynarodowych, w: Stosunki międzynarodowe w XXI wieku. Księga jubileuszowa z okazji 30-lecia Instytutu Stosunków Międzynarodowych Uniwersytetu Warszawskiego, red. E. Haliżak i in., Warszawa 2006, s. 41.

13 R. Gilpin, The Political Economy of International Relations, op. cit.

14 D. N. Balaam, M. Veseth, Introduction to International Political Economy, New Jersey 2005, s. 3.

15 S. Strange, States and Markets, op. cit., s. 16.

16 H. Milner, The Analysis of International Relations: International Political Economy and Formal Models of Political Economy, w: Cases, Numbers, Models: International Relations Research Methods, eds. D. F. Sprinz, Y. Wolinsky, Ann Arbor 2004, s. 284. 
bezpieczeństwem również uwzględniano wpływ czynników gospodarczych. Druga definicja zaproponowana przez Milner uwzględnia badanie „interakcji między rynkami i państwami, wpływ decyzji o charakterze politycznym na aktorów gospodarczych" i odwrotnie - sytuacji ekonomicznej na działania polityczne. Autorka opowiada się za definicją MEP zakładającą, że relacje gospodarcze są nierozdzielną częścią badań stosunków międzynarodowych. Należy uwzględnić przy tym nie tylko działania rządów państw narodowych, instytucji finansowych, międzynarodowych korporacji, grup społecznych, organizacji międzynarodowych, ale także instytucji niezwiązanych bezpośrednio z gospodarką: zajmujących się ochroną środowiska czy prawami człowieka. Ważnym czynnikiem jest nie tylko współpraca międzynarodowa na różnych polach, ale i konflikty - w tym militarne, szczególnie ich ekonomiczne konsekwencje ${ }^{17}$.

MEP rozwijająca się w ramach nauki o stosunkach międzynarodowych, ma również zastosowanie $\mathrm{w}$ innych dyscyplinach. Bez uznania współzależności polityki i gospodarki nie sposób napisać dogłębnej pracy z historii dyplomacji, historii gospodarczej czy politologii. Zakres badań MEP nieustannie się rozszerza, korzystając z metod stosowanych w innych naukach.

Według Roberta Gilpina, głównym zadaniem MEP jest przedstawianie wpływu światowej gospodarki rynkowej na relacje między państwami. Koncentruje się również na sposobach używanych przez państwa w celu kształtowania sił rynkowych dla osiagnięcia własnych korzyści. W relacjach między państwami narodowymi a rynkami należy rozważać trzy aspekty. Pierwszym z nich jest sposób, w jaki współzależność gospodarcza wpływa i ulega wpływom polityki międzynarodowej, szczególnie w warunkach istnienia lub braku politycznego przywództwa. „Założenie o ogromnym wpływie systemu rynkowego na wojnę lub pokój, porządek lub chaos, imperializm lub samostanowienie, wywołuje ważne pytanie: czy liberalna gospodarka światowa wymaga istnienia hegemona, który zarządzałby systemem"18. Według autora jest to niezbędne, dlatego uważał wzrost Japonii i innych umacniających się gospodarek za poważne wyzwanie dla systemu oraz przede wszystkim dla Stanów Zjednoczonych i Europy Zachodniej.

Drugim aspektem badań są interakcje między zmianami politycznymi i gospodarczymi, które dają impuls intensyfikacji konkurencji pomiędzy państwami o wpływy gospodarcze w różnych częściach świata. Najważniejsza jest odpowiedź na pytanie, jak prosperity lub niestabilność ekonomiczna wpływa na relacje między nimi oraz jak czynniki polityczne działają na kształt i konsekwencje zmian strukturalnych gospodarki rynkowej. Można też badać, czy destabilizacja gospodarcza może być powodem radykalnych działań politycznych, takich jak ekspansja, rewolucja polityczna czy wojna. Naukowcy zajmują się również poszukiwaniem odpowiedzi na pytanie, jak zderzenie między dążeniem państw do wewnętrznej autonomii i potrzebą istnienia międzynarodowych zasad może być złagodzone.

Ostatnim wymienionym przez R. Gilpina obszarem badawczym jest mierzenie wpływu rynku światowego na rozwój gospodarczy poszczególnych krajów oraz określenie wpływu państw na zasady i instytucje rządzące handlem, zagranicznymi inwe-

17 Ibidem, s. 285-286.

18 R. Gilpin, The Political Economy of International Relations, op. cit., s. 8-11. 
stycjami, systemem monetarnym i innymi aspektami międzynarodowej ekonomii politycznej. Za tymi pozornie technicznymi kwestiami kryją się ważne zagadnienia polityczne, które wpływają na siłę, współzależność i dobrobyt poszczególnych państw. Chociaż handel powinien przynosić korzyści wszystkim stronom, każde państwo stara się uzyskać nieproporcjonalnie duże zyski, chce mieć ważny głos w podejmowaniu decyzji co do zasad rządzących międzynarodowym systemem monetarnym. Dlatego na każdym obszarze międzynarodowych relacji gospodarczych, kwestie polityczne odgrywają istotną rolę ${ }^{19}$.

Helen Milner, roztaczając szerokie spektrum badawcze MEP, wyróżnia trzy dominujące tematy: 1) badania nad przyczynami odmiennej dynamiki rozwoju poszczególnych krajów i regionów; 2) wpływ międzynarodowych stosunków gospodarczych na politykę wewnętrzną państw i globalne współzależności; 3) sposoby wykorzystywania przez państwa potencjału politycznego i gospodarczego do realizacji celów w polityce wewnętrznej i międzynarodowej ${ }^{20}$.

Roger Tooze określa zakres badań MEP jako analizę współoddziaływania obszarów międzynarodowych stosunków gospodarczych, międzynarodowych stosunków politycznych oraz wewnętrznej polityki i gospodarki poszczególnych państw. Szczególną uwagę zwraca na handel międzynarodowy, międzynarodowe finanse, problemy gospodarki światowej, relacje Północ-Południe i działanie wielonarodowych korporacji ${ }^{21}$.

Handel międzynarodowy znajdował się w centrum badań MEP, ze względu na jego duże znaczenie polityczne. Jego analiza pozwala odnotować najważniejsze napięcia między państwem a rynkiem $\mathrm{w}$ danej epoce, a także dostrzec potencjalne konflikty międzynarodowe, które mogą wyniknąć z nieporozumień gospodarczych. Badając handel międzynarodowy należy brać pod uwagę fakt, że granice rynków są dynamiczne i rzadko pokrywają się ze sztywnymi granicami państw. Niektóre z nich mają globalny zasięg. Jednak handel międzynarodowy jest przedmiotem politycznego nadzoru. Analizując wpływ wymiany na stosunki międzynarodowe należy brać pod uwagę cele państw i grup interesów oraz siłę, dzięki której mogą je realizować. Nieodzowna jest także obserwacja zachowań poszczególnych aktorów w międzynarodowym systemie handlowym, który pozwala rozwiązywać potencjalne konflikty ${ }^{22}$.

W czasie zimnej wojny poza blokiem komunistycznym był on kształtowany przez hegemonię Stanów Zjednoczonych i był narzędziem strategii tego państwa w stosunkach Wschód-Zachód. W latach osiemdziesiątych i dziewięćdziesiątych XX wieku MEP zajęła się badaniem integracji gospodarczej, uznając handel za narzędzie konsolidacji interesów regionalnych. W erze globalizacji i zaawansowanych technologii, handel rozpatrywany jest w jeszcze szerszym, światowym kontekście.

Równie ważne są wpływy polityczne na międzynarodowe finanse: politykę kursów wymiany, międzynarodowy przepływ kapitału oraz państwowe i globalne struktury

19 Ibidem, s. 12-24.

20 Ibidem, s. 286-288.

21 R. Tooze, Perspectives and Theory: A Consumer's Guide, w: Key Concepts in International Political Economy, ed. D. A. Baldwin, vol. 1, Vermont 1993, s. 82.

22 B. Cohen, The Political Economy of International Trade, „International Organization”, Spring 1990, s. 281. 
polityczne i instytucje. Podczas zimnej wojny stosunki międzynarodowe rozpatrywano przede wszystkim w kontekście konfliktu Wschód-Zachód. Jednakże wzrost znaczenia handlu i przepływu kapitału wymuszał również zajęcie się relacjami Północ-Południe (zakładając, że Północ to kraje rozwinięte, a Południe - rozwijające się, co nie zawsze pokrywa się z ich położeniem na mapie świata). Zainteresowanie wzbudzało też badanie relacji wewnątrzblokowych, ze względu na polityczno-ekonomiczne napięcia między Stanami Zjednoczonymi a Europą Zachodnią i Japonią.

W czasie zimnej wojny analiza miejsca krajów rozwijających się na arenie międzynarodowej była podporządkowana rywalizacji między Wschodem a Zachodem. Publicysta „New York Times” Thomas Friedman nazwał strategię stosowaną przez obie strony strategią „książeczki czekowej i szachownicy” (ang. checkbook and the chessboard), co odnosiło się do pomocy gospodarczej tym krajom, by zapewnić sobie w nich wpływy i nie dopuścić do ich aliansu z zimnowojennym przeciwnikiem. Jako przykład takich działań można podać zaangażowanie się Stanów Zjednoczonych na Bliskim Wschodzie, a Europy Zachodniej w Afryce ${ }^{23}$. Po zakończeniu zimnej wojny naukowcy badali relacje, według określenia Immanuela Wallersteina, między centrum (ang. core) a peryferiemi (ang. periphery). Brali pod uwagę rozwój gospodarczy, zjawisko tzw. neokolonializmu i neoimperializmu.

Korporacje wielonarodowe (ang. multinational corporations - MNCs) od początku badań MEP były postrzegane jako kluczowi aktorzy stosunków międzynarodowych. Raymond Vernon zdefiniował te przedsiębiorstwa jako ,grono korporacji różnego pochodzenia narodowego, złączone poprzez więzy wspólnej własności i podlegające wspólnej strategii zarządzania”24. Według Elliota Goodmana, w latach siedemdziesiątych XX wieku nie miała już zastosowania tradycyjna teoria handlu mówiąca, że państwa ustalają wszystkie jego warunki. Wielonarodowe korporacje eksportowały kapitał, technologię i techniki zarządzania. Państwo narodowe miało być tylko punktem odniesienia - działając na forum międzynarodowych organizacji gospodarczych i zawierając umowy międzypaństwowe liberalizujące wymianę ${ }^{25} . \mathrm{Z}$ drugiej strony udowadniano, że przedsiębiorstwa pochodzące ze Stanów Zjednoczonych i Europy Zachodniej były powiązane z własnymi rządami przez „niewidzialne podanie ręki” (ang. invisible handshake). Rządy państw zachodnich używały narzędzi politycznych, by stwarzać dogodne warunki na rynkach zagranicznych dla współpracujących z nimi firm, które w zamian działały w gospodarczym, a czasem politycznym interesie kraju pochodzenia ${ }^{26}$.

Po zakończeniu zimnej wojny, wzrost ,azjatyckich tygrysów” i rosnąca globalizacja produkcji i finansów zapoczątkowała badania nad rolą przedsiębiorstw wielonarodowych w alokacji kapitału i kontroli nad technologią. Coraz częściej kwestionowano

23 A. Shonfield, The Economic Factor in International Relations, „International Affairs”, November 1970, s. 123.

24 R. Vernon, The Economic and Political Consequences of Multinational Enterprises, Boston 1972

25 E. R. Goodman, The Impact of the Multinational Enterprise upon Atlantic Community, w: The New Europe and the US. Partners or Rivals, ed. G. Mally, Lexington 1974, s. 247.

${ }^{26}$ R. Keohane, Van Doorn Ooms, The Multinational Enterprise and World Political Economy, „International Organization”, Winter 1975, s. 120. 
ich silne związki z rządami rodzimych państw, bo to one same ustalały strategie biznesowe, niekoniecznie w interesie tychże rządów. Poza tym różnica między państwem pochodzenia (ang. home country) i goszczącym (ang. host country) była coraz bardziej płynna. W pewnym sensie wszystkie państwa gościły przedsiębiorstwa wielonarodowe, a także rywalizowały o kapitał, technologię i miejsca pracy na rynku światowym dla wielonarodowych inwestycji. Ponieważ ulokowanie aktywności gospodarczej było coraz mniej identyfikowane z granicami państwa narodowego, badania poszły w kierunku międzynarodowej polityki gospodarczej globalnych powiązań (ang. International Political Economy of Global Commodity Chains - GCCs). Analizowano złożone sieci łączące niezależne przedsiębiorstwa $\mathrm{w}$ procesach skoordynowanej produkcji i dystrybucji. Niezależne firmy, dzięki rozwojowi technologii i komunikacji, często skupiały się na planowaniu i marketingu, a nie na produkcji. Zajmowały się nią inne niezależne przedsiębiorstwa.

Współcześnie badania MEP skupiają się wokół wielowymiarowego zjawiska globalizacji. Michael Veseth zauważył, że jest to wyraźne odejście od tradycyjnie rozpatrywanych stosunków międzynarodowych, w których głównymi aktorami są państwa. Dlatego MEP jest często postrzegana jako samodzielna dyscyplina. Stawia pytania o wpływ globalizacji na politykę, biznes, kulturę, technologię, środowisko, migracje, relacje płciowe, turystykę i wszelkie inne dziedziny życia. W tym kontekście często podważana jest dominująca rola państwa narodowego. Wielu naukowców uważa, że zostało ono znacznie osłabione przez procesy globalizacyjne. Twierdzą że jest za małe, by samodzielnie i efektywnie radzić sobie z problemami globalnymi, a za duże, by dobrze administrować sprawy lokalne. Państwo egzystuje więc gdzieś pośrodku (ang. in the ,missing middle”) w globalnym porządku społecznym ${ }^{27}$.

\section{METODY BADAWCZE MEP}

MEP stara się wyjaśniać międzynarodowe i globalne problemy używając interdyscyplinarnych metod analitycznych i teoretycznych. Kluczowa jest paralelna analiza gospodarcza i polityczna danej sytuacji, przy użyciu narzędzi wypracowanych przez ekonomię (zmienne i modele ekonomiczne) i nauki polityczne (kontekst polityczny). W stosunkach międzynarodowych wyróżnia się trzy główne metody analizy: studia przypadków, analizę statystyczną i tworzenie modeli formalnych ${ }^{28}$.

Według Johna S. Odella, metody jakościowe, czyli studia przypadków, są najbardziej przydatne do tworzenia teorii w MEP. Definiując przypadek jako ,przykład klasyfikacji wydarzeń lub zjawisk interesujących badacza" w określonej kwestii, np. negocjacji handlowych, J. S. Odell wyodrębnia dwie kategorie dla tej metody: studium

27 M. Veseth, International Political Economy, artykuł z UNESCO International Encyclopedia Project 2004, http://www.pugetsound.redu/x12490.xml (14.12.2010).

28 A. Mintz, The Method-of Analysis - a Problem in International Relations, w: New Directions for International Relations. Confronting the Method - of Analysis Problem, eds. A. Mintz, B. Russet, Lanham 2005, s. 13. 
pojedynczego przypadku i metodę porównawczą wielu przypadków (różnicowania). Ta pierwsza kategoria zawiera:

1) deskryptywne studium przypadku - jest to dokumentacja ważnego wydarzenia;

2) ilustrację teorii - autorzy udowadniają, że założenia danej teorii mają odzwierciedlenie w praktyce;

3) interpretację wybranych wydarzeń poprzez istniejące teorie - metoda może prowadzić do potwierdzenia lub modyfikacji teorii;

4) studium przypadku generujące nowe hipotezy.

Metoda różnicowania zasadza się na „porównywaniu przypadków, w których występuje dane zjawisko z przypadkami podobnymi pod innym względem, w których dane zjawisko nie występuje, 29 .

Według J. S. Odella, badania jakościowe najlepiej służą budowaniu spójnej teorii, gdyż jej podstawę empiryczną stanowią realne zjawiska i wydarzenia. Dlatego metody jakościowe mogą dostarczyć więcej danych niż wyłącznie statystyczne. Umożliwiają również umieszczenia zjawisk w szerszym kontekście, wyjaśnienie mechanizmów podejmowania decyzji, a analizując wiele przypadków łatwiej stworzyć lub wybrać teorię najczęściej sprawdzającą się w praktyce. J. S. Odell zauważa także słabe strony tej metody: subiektywny wybór przypadków przez badaczy może prowadzić do wyciagania krańcowo różnych wniosków. Realia stosunków międzynarodowych mogą dostarczyć dowodów na potwierdzenie różnorakich teorii. Poza tym dane statystyczne w większym stopniu precyzują występowanie danego zjawiska i uwiarygodniają wnioski. Dlatego autor postuluje uzupełnianie studiów przypadku o metody statystyczne. Takie rozwiązanie niweluje słabe strony obu metod ${ }^{30}$.

W MEP stosuje się także metody ilościowe, wykorzystując dane statystyczne. W większości prac autorzy badają jak czynniki polityczne kształtują handel zagraniczny. Szczególnie dotyczy to globalnej dystrybucji władzy i kształtowania przez państwa systemu globalnego handlu. Do mierzenia siły wpływów państw tradycyjnie bierze się pod uwagę czynniki takie jak: wielkość i dynamikę PKB, ludność, wydatki militarne i dywersyfikację geograficzną eksportu i importu. Bada się również wpływ sojuszy i konfliktów na wymianę i inwestycje ${ }^{31}$. Wadą stosowania wyłącznie tej metody jest brak szerszego kontekstu, który zapewniają metody jakościowe.

W miarę rozwoju MEP, coraz bardziej popularne stało się tworzenie modeli formalnych. W MEP są one w przeważającej mierze oparte na teorii racjonalnego wyboru. Zakłada ona, że racjonalne jednostki konsekwentnie realizują cele, posiadając kompletną wiedzę o warunkach wpływających na ich decyzje. Aktorzy działają w taki sposób, by osiagnąć maksymalną użyteczność. Teoria oparta na tych założeniach ma wskazać najlepszą drogę do realizacji wyznaczonych celów. Tworzone modele formalne ułatwiają porównanie kosztów i korzyści z konkretnych posunięć, a racjonalny aktor wybiera najlepsze $\mathrm{z}$ nich. Formalizacja polega więc na transformacji wszystkich

29 J. S. Odell, Case Study Methods in International Political Economy, w: Cases, Numbers, Models, op. cit., s. 65-70.

30 Ibidem, s. 70-84.

31 E. D. Mansfield, Quantitative Approaches to the International Political Economy, w: Cases, Numbers, Models, op. cit., s. 164-189. 
czynników wpływających na decyzje aktorów stosunków międzynarodowych w dedukcyjny, matematyczny schemat - model. Zawiera on explicite założenia danej analizy; funkcje zysków i strat danego aktora; działania, jakie może podjąć na każdym etapie oraz posiadane przez niego informacje i przekonania na temat danej sytuacji. Wszystkie te czynniki wyrażone są za pomocą pojęć matematycznych.

W MEP za pomocą modeli formalnych bada się najczęściej trzy obszary: teorię hegemonicznej stabilności (aby wykazać, w jakich okolicznościach najsilniejsze państwo i jego sojusznicy dążą do stworzenia otwartego systemu handlowego), zagraniczną politykę gospodarczą (aby przewidzieć preferencje poszczególnych aktorów) oraz uwarunkowania szeroko pojętej współpracy międzynarodowej (badanie przydatności instytucji). Milner wykazuje przydatność tworzenia modeli formalnych. Przyznaje jednak, że w pracach z zakresu MEP muszą być one uzupełniane obszernymi komentarzami werbalnymi. Za największą słabość tej metody uznaje założenie, że aktorzy posiadają komplet informacji o danej sytuacji. Ze względu na wielość czynników na nią wpływających jest to niemożliwe, więc przetwarzanie danych w proponowany sposób jest mało precyzyjne ${ }^{32}$.

W badaniu stosunków międzynarodowych stosuje się też metodę systemową. Jej celem jest stworzenie modelu zjawisk, biorąc pod uwagę wszystkie elementy kształtujące określoną rzeczywistość. Metoda decyzyjna polega na badaniu wpływu różnych ośrodków decyzyjnych na zmiany w systemie ${ }^{33}$. Analizuje się sprzężenie czynników politycznych i gospodarczych w ramach systemu. Bardzo istotne jest funkcjonowanie ośrodków decyzyjnych (rządów państw, instytucji, organizacji międzynarodowych, wielonarodowych korporacji), od których decyzji zależy kształt wzajemnych relacji na wszystkich polach.

W najnowszych opracowaniach autorzy dostrzegają potrzebę łączenia różnorodnych metod, żeby podejść do badanego problemu z wielu punktów widzenia. Stosowanie tylko jednego schematu analizy prowadzi do sytuacji, że autorzy rozważając ten sam problem, dochodzą do sprzecznych wniosków, np. jedni twierdzą że handel pomaga w utrzymaniu pokoju, inni uważają, że nie ma na to wpływu. Alex Mintz twierdzi, że podważa to wiarygodność badań stosunków międzynarodowych, dlatego politycy tak rzadko korzystają $z$ dorobku naukowców ${ }^{34}$. Problem polega jednak na tym, że obie przytoczone tezy o wpływie handlu międzynarodowego na stosunki międzynarodowe można udowodnić przytaczając konkretne przykłady relacji między państwami. W tym przypadku potrzebna jest kompleksowa analiza całokształtu sytuacji, tj. historii wzajemnych relacji, otoczenia międzynarodowego, potencjału poszczególnych państw, łączących ich interesów politycznych i gospodarczych, czynników socjologicznych, kulturowych i wielu innych.

Bruce Russet postulował konieczność stosowania różnorodnej metodologii ze względu na większe możliwości badawcze we współczesnym świecie. Miał przede wszystkim na myśli masową dostępność materiałów i danych statystycznych (też przez internet), co pozwala w pełni uwzględniać czynniki ekonomiczne w stosunkach mię-

32 H. Milner, op. cit., s. 293-300.

33 A. J. Chodubski, Wstęp do badań politologicznych, Gdańsk 2006, s. 119.

34 A. Mintz, op. cit., s. 5. 
dzynarodowych. Dzięki temu wzrosła również jakość empirycznej analizy weryfikującej wypracowywane teorie. $Z$ tym zjawiskiem związane jest wymaganie łączenia metod badawczych (tzw. network analysis) i zastępowanie tradycyjnych schematów nowymi. B. Russet zauważa, że na zmiany w badaniu stosunków międzynarodowych decydujący wpływ miało zakończenie zimnej wojny, i to nie tylko ze względu na przeobrażenia w układzie sił na świecie. Stwierdził, że naukowcy zaczęli zwracać większą uwagę na implikacje polityki wewnętrznej państw i globalne skutki działań wszystkich aktorów stosunków międzynarodowych ${ }^{35}$.

\section{GLÓWNE NURTY TEORETYCZNE MEP}

Pierwsze teorie MEP opierały się na trzech głównych perspektywach badań stosunków międzynarodowych: realizmie (definiowanym jako merkantylizm/neomerkantylizm lub nacjonalizm gospodarczy), liberalizmie i marksizmie (określanym jako strukturalizm).

Neomerkantylizm zakładał podporządkowanie gospodarki państwu i jego interesom - głównie związanym z dobrobytem wewnętrznym i międzynarodowym bezpieczeństwem gospodarczym. Jego zwolennicy podkreślali znaczenie potencjału gospodarczego, a nie militarnego. Według tej teorii, międzynarodowe relacje ekonomiczne mają charakter konfliktogenny i są zdominowane przez rosnącą ingerencję rządu w gospodarkę. Ponieważ relacje gospodarcze są determinowane przez politykę, ich badanie ma sens tylko w kontekście państw ${ }^{36}$.

Podstawowym założeniem liberalizmu jest zasadniczo harmonijna natura relacji gospodarczych. Największą wartością jest efektywność, stawiana nad innymi wartościami społecznymi. Koncepcję gospodarczą świata opierano na procesie równoważenia globalnego dobrobytu. Rola państwa sprowadza się do zapewnienia bezpiecznych politycznych ram działania dla realizacji tych celów.

Teoria liberalna podkreśla wagę relacji państwo - społeczeństwo, a przede wszystkim międzynarodowe współzależności. Według liberałów, zachowanie państw odzwierciedla ich zmienne interesy. Rządy starają się osiągnąć wyznaczone cele w stosunkach międzynarodowych za pomocą prowokowania konfliktu lub organizowania współpracy, w zależności od aktualnej sytuacji i narzędzi polityki zagranicznej, które mają do dyspozycji. Muszą się przy tym liczyć z interesami innych państw. Teoria ta odrzuca więc założenie realizmu o nieuniknionym konflikcie interesów między państwami narodowymi. Polityka współzależności polega bowiem na równoważeniu zysków i strat w relacjach międzynarodowych ${ }^{37}$.

Neoliberalizm, zwany też liberalnym instytucjonalizmem, zakłada konieczność współpracy państw w ramach międzynarodowych instytucji. Jego zwolennicy uznają kluczowe znaczenie państw, ale podkreślają wpływy niepaństwowych uczestników

35 B. Russett, Four Methods and Five Revolutions, w: New Directions, op. cit., s. 21-23.

36 F. L. Block, The Origins of International Economic Disorder, Berkeley 1977.

37 A. Moravcsik, Taking Preferences Seriously: A Liberal Theory of International Politics, „International Organization", Autumn 1997, s. 514-520. 
stosunków międzynarodowych, takich jak organizacje międzynarodowe, korporacje wielonarodowe, kościoły, związki zawodowe, organizacje pozarządowe itp. Według nich, anarchię konkurujących interesów wielu aktorów stosunków międzynarodowych, mogą okiełznać międzynarodowe reżimy.

Termin „współzależność” pojawił się w nauce o stosunkach międzynarodowych pod koniec lat sześćdziesiątych XX wieku na określenie rosnących powiązań handlowych, inwestycyjnych i monetarnych gospodarek narodowych. Powodowało to zmniejszenie się autonomii państw, gdyż były narażone na coraz więcej negatywnych efektów ekonomicznych i miały coraz mniejszą możliwość panowania nad nimi. Współzależność dotyczyła także polityki zagranicznej i bezpieczeństwa ${ }^{38}$. Uważano za nieuniknione, że siły ekonomiczne przeważą polityczne w stosunkach międzynarodowych ${ }^{39}$. Świadczył o tym znaczny wzrost przepływu kapitału i technologii, rozwój wielonarodowych przedsiębiorstw, zwiększenie znaczenia globalnych instytucji, także pozarządowych, większa otwartość granic oraz pojawienie się w polityce zagranicznej nowych czynników, takich jak prawa człowieka czy bezpieczeństwo energetyczne ${ }^{40}$.

W latach siedemdziesiątych i osiemdziesiątych XX wieku toczyła się debata między neorealistami i neoliberałami. Neorealiści wysuwali argumenty o podstawowym znaczeniu dystrybucji siły między państwami w systemie. Uważali, że współpraca między nimi jest trudna, gdyż silniejsze państwa mają z niej większe zyski. Twierdzili, że organizacje międzynarodowe mają znikome znaczenie. Priorytetem w polityce państwa jest bezpieczeństwo militarne, a kwestie ekonomiczne i społeczne mają znaczenie drugorzędne. Debata doprowadziła do zbliżenia stanowisk między neorealistami a neoliberałami. Ci pierwsi zaczęli w większym stopniu doceniać znaczenie współpracy międzynarodowej, a ci drudzy - dominującą rolę państw narodowych ${ }^{41}$.

Robert Keohane i Joseph Nye wprowadzili pojęcia „wrażliwości” - sensitivity i ,podatności na zranienia" - vulnerability. Pierwsze określenie dotyczy stopnia podatności państw na zmiany mające miejsce w innych krajach. Natomiast vulnerability określa, jakie koszty ponoszą w wyniku tych zmian poszczególne państwa. Autorzy wskazywali, że ich dystrybucja jest nierównomierna. Wypracowali również teorię złożonej współzależności - complex interdependence, która podważała główne założenia realizmu. Twierdzili, że nie tylko stosunki międzypaństwowe, ale także działania innych aktorów wpływają na rządy i osłabiają ich zdolność autonomicznego kształtowania stosunków międzynarodowych. R. Keohane i J. Nye obalili przekonanie o hierarchiczności podziału polityki na priorytetową high politics odnoszącą się do bezpieczeństwa i drugorzędną low politics relacji handlowych, nazywając ten podział anachronicznym. Utrzymywali, że zmiany gospodarcze nie zepchną polityki w cień, ale sprawią, że ulegnie ona zasadniczym przeobrażeniom.

38 R. Cooper, op. cit., s. 67-69.

39 The Theoretical Evolution of International Political Economy: A Reader, eds. G. T. Crane, A. Amawi, Oxford 1997, s. 13.

40 M. Griffiths, T. O'Callaghan, International Relations. The Key Concepts, London 2001, s. 157.

41 J. Czaputowicz, Teorie stosunków międzynarodowych. Krytyka i systematyzacja, Warszawa 2008, s. 238-241. Więcej na temat rozbieżności między neorealistami a neoliberałami zob.: D. A. Baldwin, Neorealism and Neoliberalism: The Contemporary Debate, New York 1993. 
Strukturalizm analizował rozwój światowej polityki ekonomicznej jako całości, nie skupiając się na poszczególnych państwach. Zakładano, że najbogatsi kształtują i podtrzymują struktury światowego systemu w celu maksymalizacji zysków, co odbywa się kosztem peryferii ${ }^{42}$. Traktuje również kwestie gospodarcze i polityczne jako całość, ale skupia się na światowym systemie kapitalistycznym, a nie na narodach funkcjonujących w tym systemie ${ }^{43}$.

Ze strukturalizmu wywodzi się teoria zależności (ang. dependence theory) i peryferiów (ang. dependency theory). Różnicę między nimi tłumaczył James Caporaso. Dependence to skrajnie asymetryczna forma współzależności, np. gdy państwo polega w jakiejś dziedzinie całkowicie na innym aktorze stosunków międzynarodowych, który nie jest w żaden sposób od niego uzależniony. Natomiast dependency to proces włączania krajów rozwijających się w system kapitalistyczny, co powoduje zniekształcenia strukturalne i hamuje rozwój. J. Caporaso przeciwstawia obu tym teoriom koncepcję współzależności (ang. interdependence) rozumianą jako zależność od wielostronnej kontroli, przyjętej dobrowolnie ze względu na wspólnotę interesów - przeciwieństwo autarkii i izolacjonizmu ${ }^{44}$.

Silnie opierająca się na marksizmie teoria nowoczesnego systemu światowego (ang. Modern World System - MWS) zakłada, że rynek światowy to narzędzie ekonomicznej eksploatacji mniej rozwiniętych krajów przez zaawansowane gospodarki kapitalistyczne. MWS jest zdefiniowany przez Immanuela Wallersteina jako „podział pracy, w którym produkcja i wymiana podstawowych dóbr jest niezbędna dla życia codziennego". Świat jest jednym systemem, rządzącym się określonymi prawami ekonomicznymi. Teoria zakłada prymat interesów gospodarczych i walki klas nad konfliktami politycznymi i społecznymi w determinowaniu zachowań ludzkich. Kapitalizm, który jest podstawą systemu, wytwarza zahamowania rozwojowe: polityczne i gospodarcze poprzez wykorzystywania peryferii przez silne centra gospodarki światowej ${ }^{45}$.

Charakterystyczne dla rozwoju MEP było powstawanie perspektyw krytycznych wobec głównych nurtów. Podejście ekologiczne opierało się na założeniu, że naturalne środowisko to jeszcze jedna wartość, którą trzeba rozpatrywać oprócz takich czynników jak bezpieczeństwo, wolność i sprawiedliwość. Krytyka feministyczna uświadamiała, że świat nie składa się tylko z państw i rynków czy proletariatu i burżuazji, ale z kobiet i mężczyzn. Przy analizie stosunków międzynarodowych należy więc brać pod uwagę dominację mężczyzn w instytucjach oraz stereotypy kulturowe przypisywane płciom $^{46}$. Wielu badaczy twierdziło, że MEP jest nauką postmodernistyczną, gdyż obala pogląd, że ekonomiści mają zajmować się wyłącznie ekonomią, a politolodzy-polityką ${ }^{47}$.

42 J. Petras, Critical Perspectives on Imperialism and Social Class in the Third World, New York 1978.

43 P. Baran, The Political Economy of Growth, New York 1957.

44 J. A. Caporaso, Dependence, Dependency, and Power in the Global System: a Structural and Behavioral Analysis, „International Organization”, Winter 1978, s. 18-21.

45 I. Wallerstein, The Modern World System: Capitalist Agriculture and the Origins of European World Economy in the Sixteenth Century, New York 1974.

${ }^{46}$ J. Steans, Gender and International Relations: Issues, Debates and Future Directions, Cambridge 2006.

47 D. N. Balaam, M. Veseth, op. cit., s. 108. 
Postmoderniści twierdzili, że w naukach społecznych nie sposób stworzyć jednolitych teorii, wyodrębnić stałych praw rządzących życiem społecznym i ściśle zdefiniowanych aktorów. Stosunki międzynarodowe to mieszanka przeciwstawnych sił skonfliktowanych tożsamości, które wymykają się jakiejkolwiek klasyfikacji czy kontroli ${ }^{48}$.

Żadna teoria nie opisywała dynamiki sytuacji międzynarodowej w sposób doskonały. Stąd postulat, wyartykułowany m.in. przez Jacoba Reuveny'ego, „otwartości teorii” (theoretical openess). Według niego badania naukowe powinny thumaczyć konkretną sytuację bądź zjawisko, które nie zawsze zgadzają się z założoną teorią. Autor zauważa również konieczność rezygnacji z podejścia ideologicznego ${ }^{49}$.

\section{CZYNNIK GOSPODARCZY W POLITYCE ZAGRANICZNEJ PAŃSTWA}

Perspektywy MEP opierają się na obserwacji zmieniającej się sytuacji politycznej i gospodarczej. W tej części artykułu zostaną przedstawione wybrane teorie uwzględniające badanie wpływu czynników ekonomicznych na politykę zagraniczną państw narodowych. Można je zastosować do tłumaczenia mechanizmów podejmowania decyzji przez administrację Stanów Zjednoczonych w latach siedemdziesiątych XX wieku, szczególnie w relacjach transatlantyckich.

Brytyjska badaczka - Susan Strange twierdziła, że międzynarodowy system gospodarczy rozwijał się szybciej niż polityczny, w związku z czym relacje polityczne musiały ulec zmianie. Nie zgadzała się $\mathrm{z}$ tezą, że doprowadzi to do zaniku państw narodowych, ale przewidywała nieuchronne przeobrażenia w polityce zagranicznej i wewnętrznej. W odpowiedzi na nowe wyzwania gospodarki światowej, państwa miały zacieśniać współpracę, albo stosować mechanizmy obrony własnych gospodarek ${ }^{50}$.

David N. Baalam i Michael Veseth, zwracali uwagę na interakcję w systemie międzynarodowym między państwami i rynkami. Powodem napięć między tymi aktorami jest fakt, że państwo w większym stopniu kieruje się interesami politycznymi, a rynek gospodarczymi (zyskiem). Dlatego istnieje sieć umów między aktorami związanymi z państwem i rynkiem. Ich działanie jest uzależnione od siły poszczególnych podmiotów ${ }^{51}$.

Edward Haliżak wyróżnia poszczególne obszary wzajemnych oddziaływań strefy politycznej i ekonomicznej. Pierwszą z nich jest właśnie rola czynnika ekonomicznego w polityce państw. W jej analizie należy uwzględniać zarówno czynniki ideologiczne, jak i ekonomiczne. Na czynnik ekonomiczny składa się gospodarka państw (jej aktywa i pasywa), procesy ekonomiczne (postęp techniczny, kursy walutowe, stopy procentowe, handel zagraniczny i in.), decyzje o alokacji czynników produkcji w kraju i za granicą oraz prawo i organizacje międzynarodowe.

48 The Theoretical Evolution, op. cit., s. 26-27.

49 Cyt. za: C. F. Bergsten, R. Keohane, J. Nye, International Economics and International Politics. A Framework for Analysis, w: World Politics and International Economics, eds. C. F. Bergsten, L. B. Krause, Washington 1975, s. 11.

50 S. Strange, International Economics and International Relations: A Case of Mutual Neglect, op. cit., s. 306-313.

51 D. N. Balaam, M. Veseth, op. cit., s. 13-21. 
Działania państwa o charakterze ekonomicznym oraz sytuacja gospodarcza na jego obszarze wpływa na relacje międzynarodowe. Państwo może je kształtować poprzez stosowanie sankcji ekonomicznych, ale też przyznając koncesje gospodarcze państwom otwartym na współpracę. W dobie współzależności ekonomicznych, rządy starają się także zapewnić dostęp do rynków innych państw poprzez umowy lub integrację. Są również zainteresowane ochroną interesów rodzimych firm za granicą ${ }^{52}$.

Tak jak harmonijna współpraca ekonomiczna wpływa pozytywnie na kształtowanie się stosunków między państwami, tak rozbieżności na tym polu mogły negatywnie wpływać na relacje polityczne. W takim przypadku rozwiązanie problemów jest zależne od wielu czynników. Pierwszym z nich jest stopień współzależności politycznej. Państwa, które są połączone siecią wspólnych interesów na arenie międzynarodowej, są bardziej skłonne do kompromisu w kwestiach ekonomicznych. W tym przypadku ważna jest również siła polityczna, często poparta przewagą militarną. Państwo dominujące w systemie sojuszy ma większe możliwości przeforsowania decyzji.

Drugim, złożonym czynnikiem jest stopień współzależności gospodarczych. Podobnie jak w przypadku powiązań politycznych, państwa funkcjonujące $\mathrm{w}$ jednym systemie gospodarki światowej, wzajemnie siebie potrzebują. Należy przy tym rozpatrywać siłę ekonomiczną poszczególnych podmiotów. W momencie zmierzchu hegemonii gospodarczej Stanów Zjednoczonych, dynamicznego rozwoju Japonii i umocnienia się europejskiej integracji pod koniec lat sześćdziesiątych XX wieku, siły w systemie zachodnim stały się bardziej wyrównane ${ }^{53}$.

Przy analizie uwarunkowań polityki zagranicznej państw posługiwano się najczęściej perspektywami związanymi z realizmem. Teoria państwocentryczna: statyzm zakładała, że państwo narodowe jest zintegrowane, zamykające się na kontakty zewnętrzne, co je wewnętrznie spaja i umacnia. Działa ono na arenie międzynarodowej, by wypracować dla siebie jak najkorzystniejsze warunki. Teoretycznie państwo jest jedyną instytucją polityczno-gospodarczą posiadającą suwerenność zewnętrzną i wewnętrzną. Jednak realnie te jego atrybuty są ograniczone. Stephen D. Krasner podkreślał, że interesy ekonomiczne jednostek często pozostają w sprzeczności z interesem państwa $^{54}$.

Teoria polityki biurokratycznej (ang. bureacratic politics) podkreślała rolę administracji i biurokracji w kształtowaniu polityki. Również polityka zagraniczna państwa miała być efektem kompromisu między wieloma urzędami, a nawet jednostkami odpowiedzialnymi za jej kształtowanie. Różne ośrodki władzy forsują bowiem odmienne rozwiazzania. Dlatego kwestionowano istnienie jednolitej polityki zagranicznej państwa. Teoria ta nie zakłada, że zawsze interesy polityczne państwa dominują nad siłami gospodarczymi. Zauważa raczej skomplikowane współzależności między tymi dwoma obszarami. Patrząc przez pryzmat państwa, stara się wyjaśnić, w jakich okolicznościach interesy polityczne dominują nad gospodarczymi i odwrotnie. Perspektywa ta definiuje państwo jako związek sił instytucjonalnych, które wykształciły się na prze-

52 E. Haliżak, Współzależność polityki i ekonomii, op. cit., s. 41.

53 Ibidem, s. 42.

54 S. Krasner, Defending the National Interest: Raw Materials, Investment and American Foreign Policy, Princeton 1978. 
strzeni dziejów. Dlatego państwa różnią się charakterem struktur organizacyjnych i mają różne interesy narodowe. Jednak celem każdego z nich jest kontrola nad określonym terytorium. Są stworzone, by dominować nad wewnętrznymi siłami społecznymi i opierać się zagrożeniom zewnętrznym. Państwo pośredniczy między światowymi a wewnętrznym siłami polityczno-ekonomicznymi ${ }^{55}$.

Bliska politycznemu realizmowi jest teoria hegemonicznej stabilności (ang. hegemonic stability). Jej nazwę do nauki o stosunkach międzynarodowych wprowadził Robert Keohane, lecz jej główne założenia wyartykułowali wcześniej w swoich pracach Charles Kindleberger, Robert Gilpin i Stephen D. Krasner ${ }^{56}$. Hegemonem nazwano bogate i silne militarnie państwo, które podejmuje wysiłek dostarczenia dóbr publicznych dla systemu międzynarodowego. Te dobra to stabilna waluta, bezpieczeństwo i system wolnego handlu, który dobrze działa tylko wtedy, gdy należy do niego jak najwięcej państw. Zapewnienie trwania takiego systemu wymaga wielu nakładów, ale jest opłacalne dla hegemona nawet wtedy, gdy ponosi samodzielnie nieproporcjonalnie duże koszty. Korzysta bowiem z dominującej pozycji w systemie światowym. Inne państwa uznają dominację hegemona $\mathrm{z}$ powodu jego prestiżu i statusu w międzynarodowym systemie politycznym. Akceptują również reprezentowaną przez niego ideologię. Hegemon jest konieczny, by powstrzymać inne państwa od nieuczciwego wykorzystywania istniejącego systemu, np. poprzez odmowę ponoszenia części kosztów jego funkcjonowania lub zabezpieczania interesów kosztem innych uczestników. Na polu ekonomicznym hegemon używa wpływów do stwarzania międzynarodowych reżimów, określających prawne i bezprawne zachowania, by ograniczyć potencjalne konflikty, zapewnić równość uczestników systemu lub ułatwiać zawieranie umów. Poza tym wzrost gospodarczy hegemona działa jako siła napędowa dla wzrostu pozostałych państw. To hegemon ma największe środki, by nabywać towary i usługi od swych partnerów oraz kierować tam swoje inwestycje. Transferuje również wiedzę i technologię. Dzięki rozmiarowi gospodarki może stosować sankcje ekonomiczne, choćby przez ograniczanie dostępu do swojego rynku. Tak samo duże znaczenie ma wartość jego waluty. Jeśli stan gospodarki hegemona pogarsza się, negatywnie wpływa to na całość systemu. Jeżeli inne państwa zaczynają postrzegać działania hegemona jako służące wyłącznie jego interesom i uznają je za sprzeczne z ich własnymi celami, system hegemonii zostaje osłabiony. Dzieje się tak również w przypadku, gdy obywatele mocarstwa-hegemona dojdą do przekonania, że inne kraje nie wywiązują się z warunków umowy, lub że koszty przywództwa zaczynają przeważać nad korzyściami ${ }^{57}$.

Bergsten, R. Keohane i J. Nye wykazywali, że ingerencja rządów w międzynarodowe stosunki gospodarcze może wynikać z obaw, że przedsiębiorstwa wielonarodowe będąje kształtować w sposób sprzeczny z interesami danego państwa. Z drugiej strony, zauważając potrzebę wzrostu handlu i inwestycji zagranicznych, powstrzymywały się od ograniczania ich działalności. Autorzy uważają, że wzrost współzależności po-

\footnotetext{
55 The Theoretical Evolution of International Political Economy: A Reader, op. cit., s. 13.

56 J. Czaputowicz, op. cit., s. 203.

57 R. Gilpin, The Political Economy of International Relations, op. cit., s. 66-73.
} 
wodował, że międzynarodowe kwestie gospodarcze znajdowały się na czele listy priorytetów polityki zagranicznej rządów ${ }^{58}$.

R. Keohane i J. Nye zwrócili uwagę na ważny element współzależności, jakim były międzynarodowe organizacje, hamujące państwa członkowskie przed podejmowaniem działań godzących w interesy partnerów. Współzależność kreowała więc nowe źródła siły oraz sieć „,wzajemnych asymetrycznych zależności”,59. Rządy państw przy kreowaniu polityki musiały brać pod uwagę czynnik ekonomiczny. Autorzy ci twierdzili, że trudno określić jakąkolwiek transakcję jako czysto rynkową, gdyż odbywa się ona w określonym systemie politycznym i gospodarczym. Im lepiej te systemy działaja, tym mniej kwestie polityczne oddziałują na ekonomiczne. Jeśli jednak występują spory i niewydolność systemu uniemożliwiająca ich rozwiązanie, decyzje podejmują politycy. Nieunikniona jest wtedy eskalacja rozbieżności. Pojawia się coraz więcej kwestii spornych, wzrasta zainteresowanie tymi problemami na najwyższym szczeblu władz państwowych, co z kolei często prowadzi do pogorszenia się relacji politycznych. Dążenie do ich poprawy jest niewątpliwie czynnikiem hamującym eskalację konfliktu gospodarczego i bodźcem do podjęcia negocjacji w celu osiagnięcia kompromisu. R. Keohane i J. Nye odnosili tę konkluzje zarówno do relacji międzynarodowych, jak i wewnętrznych. Wysunęli również tezę, że wzrastające upolitycznienie międzynarodowych relacji gospodarczych wynika z faktu, że coraz częściej ekonomiczne narzędzia nacisku były stosowane $\mathrm{w}$ polityce zagranicznej ${ }^{60}$.

Stephen D. Cohen definiował międzynarodową politykę gospodarczą jako „wysiłki państwa w celu zmian w sposobie przepływu towarów, usług i kapitału, który miałby miejsce, gdyby pozwolić działać wyłącznie siłom rynkowym"61 . Wyróżnił pięć rodzajów działań państwa, czerpiąc z doświadczeń Stanów Zjednoczonych: 1) przedsięwzięcia długoterminowe, np. inicjowanie rundy negocjacyjnej na temat międzynarodowej liberalizacji handlu; 2) szybkie interwencje, np. pomoc dla kraju dotkniętego poważnym kryzysem finansowym, stanowiącym zagrożenie dla systemu; 3) dążenia do utrzymania obowiązujących warunków, np. odrzucenie wewnętrznych nacisków na wprowadzenie środków protekcjonistycznych (w tym miejscu należy zaznaczyć, że miały miejsce sytuacje, gdy państwo ulegało takim naciskom); 4) stosowanie nacisków na inne państwa, by bardziej otworzyły swe rynki na amerykański eksport; 5) wprowadzanie w życie programów gospodarczych uchwalanych przez Kongres ${ }^{62}$. S. D. Cohen podkreśla wagę międzynarodowej polityki gospodarczej twierdząc, że zawierają się w niej dwa najważniejsze cele państwa: bezpieczeństwo narodowe i wewnętrzny dobrobyt. Zauważył, że jej prowadzenie jest uwarunkowane przez czynniki wewnętrzne, przede wszystkim konieczność wymaganej przez elektorat interwencji w gospodarkę oraz zewnętrzne - wzrost wpływu kwestii ekonomicznych na relacje międzynarodowe ${ }^{63}$.

58 C. F. Bergsten, R. Keohane, J. Nye, International Economics and International Politics, op. cit., s. 4-5.

59 R. Keohane, J. Nye, Power and Interdependence, op. cit., s. 29.

${ }^{60}$ Ibidem, s. 31-36.

61 S. D. Cohen, The Making of United States International Economic Policy. Principles, Problems, and Proposals for Reform, Westport 2000, s. 5.

${ }^{62}$ Ibidem, s. 7.

${ }^{63}$ Ibidem, s. 20-25. 
Rolę państwa w stosunkach międzynarodowych i wpływu czynnika ekonomicznego na kształtowanie jego polityki zagranicznej uwzględnił również Klaus Knorr w wydanej w 1975 r. pracy pt. The Power of Nations. The Political Economy of International Relations (Siła narodów. Ekonomia polityczna stosunków międzynarodowych). Autor wyróżnił trzy rodzaje siły państwa: militarną, ekonomiczną i polityczną zdolność rozszerzania wpływów ${ }^{64}$. Wykazywał, że państwo może użyć siły ekonomicznej, by zrealizować cele: zagrozić utratą przywilejów, wprowadzić sankcje ekonomiczne lub zachęcić ekonomicznymi koncesjami. Rząd, używając narzędzi gospodarczych, może mieć różne cele: 1) uzyskanie korzyści gospodarczych, np. poprzez ograniczenie importu, by chronić rodzimą produkcję; 2) przejęcie kontroli nad innymi państwami; 3) umocnienie siły militarnej (np. pomoc finansowa w zamian za bazy na terytorium innego państwa); 4) umocnienie sojuszy (np. poprzez inwestycje, poparcie dla integracji); 5) wsparcie dla przyjaznych i sprzymierzonych państw (np. przyznanie kredytów na korzystnych warunkach, preferencyjne układy handlowe); 6) osłabienie potencjału krajów wrogich (np. embargo na dobra strategiczne); 7) okazanie niezadowolenia z polityki państwa i nałożenie kary (np. zawieszenie pomocy gospodarczej).

Autor wyróżnił następujące cele pomocy zagranicznej: 1) krótkoterminowe gospodarcze: promocja eksportu, znalezienie rynków zbytu dla nadwyżek produkcyjnych, stworzenie dobrych warunków do inwestycji; 2) krótkoterminowe polityczno-militarne: uzyskanie stref wpływów (rywalizacja z przeciwnikiem), wspieranie przywódców państw sprzymierzonych, poprawa bezpieczeństwa militarnego, propaganda, podkreślenie zainteresowania współpraca, umocnienie sojuszu; 3) długoterminowe polityczne i gospodarcze: zrównoważony rozwój, długotrwała współpraca, demokratyzacja ${ }^{65}$.

Rolę narzędzi gospodarczych w polityce zagranicznej państwa analizował David A. Baldwin w pracy pt. Economic Statecraft ${ }^{66}$. Tytułowe pojęcie można tłumaczyć jako dyplomację gospodarczą, a konkretnie używanie instrumentów ekonomicznych przez państwo w polityce zagranicznej. Są to działania zmierzające do podniesienia pozycji międzynarodowej państwa poprzez promocję jego interesów. Celem autora było wykazanie, że te narzędzia, wbrew stereotypom, są skuteczne i w wielu przypadkach mogą stanowić alternatywę dla groźby użycia siły militarnej lub wojny. Według D. A. Baldwina dyplomacja gospodarcza składa się z trzech elementów: 1) instrumentu użytego w próbie wywarcia wpływu; 2) obszaru wpływu (inni uczestnicy stosunków międzynarodowych); 3) celu wpływu (pożądane zachowanie uczestnika stosunków międzynarodowych). Przedstawiając taką definicję, autor określa dyplomację gospodarczą jako akt o charakterze politycznym ${ }^{67}$. Za najbardziej skuteczną technikę uprawiania dyplomacji gospodarczej uznał handel zagraniczny. Zgadzał się z Thomasem Schellingiem, że

${ }^{64}$ Podział autorstwa K. Knorra ma odzwierciedlenie w pojęciach ukutych przez Josepha Nye'a: hard power - zdolność państwa do wywierania nacisku na innych aktorów za pomocą siły militarnej lub/i gospodarczej oraz soft power - ,zdolność do pozyskiwania sojuszników i zdobywania wpływów dzięki atrakcyjności własnej kultury, polityki, ideałów politycznych”. Patrz: J. Nye, Bound to Lead: The Changing Nature of American Power, New York 1990.

65 K. Knorr, The Power of Nations. The Political Economy of International Relations, New York 1975, s. 135-138; 169-170.

${ }_{67}^{66}$ D. A. Baldwin, Economic Statecraft, Princeton 1985.

${ }^{67}$ Ibidem, s. 32 
„,szeroko pojęty handel (zawierający także inwestycje zagraniczne, transport, turystykę i zarząazzanie przedsiębiorstwami), to główny składnik stosunków międzynarodowych. Dlatego polityka handlowa może antagonizować rządy, skłócić społeczeństwa, szkodzić gospodarce i wpływać na politykę poszczególnych państw" ${ }^{\text {"68 }}$. Decydenci staraja się tak kształtować politykę handlową by osiagnąc takie efekty bądź ich uniknąć. D. A. Baldwin zauważa, że większość autorów zwracało uwagę raczej na pomoc zagraniczną, która była bardziej nagłaśniana przez propagandę. Przyznaje, że w latach 1944-1962 była ona główną techniką dyplomacji gospodarczej stosowanej przez rząd Stanów Zjednoczonych. Przyczyniła się do odbudowy Europy Zachodniej (plan Marshalla) i miała na celu wspomaganie rozwoju państw Trzeciego Świata. D. A. Baldwin zauważa jednak, że głównym celem tej pomocy było wprowadzenie w tych krajach reguł wolnego handlu. Amerykanie używali polityki handlowej, by stworzyć system oparty na liberalizacji wymiany i eliminacji dyskryminujących praktyk. Najwięcej miejsca w swojej pracy autor poświęca analizie skuteczności sankcji gospodarczych, opierając ją na konkretnych przypadkach, np. embarga na towary strategiczne wobec bloku wschodniego czy sankcji nałożonych przez Stany Zjednoczone na Kubę po przejęciu władzy przez Fidela Castro. Wykazuje, że działania te miały wielorakie cele, a brak skutków w postaci rozpadu bloku komunistycznego czy ustappienia F. Castro, nie oznaczają fiaska zastosowanych sankcji.

D. A. Baldwin zwraca też uwagę na wielość czynników składającą się na siłę państw, obalając przekonanie, że powinna być ona mierzona przede wszystkim przez potencjał militarny. Jako części składowe potęgi państw wymienia: obszar geograficzny, populację bogactwo, możliwości rządu sprawnego kierowania państwem. Jeśli chodzi o politykę zagraniczną, możliwości wpływów na innych uczestników stosunków międzynarodowych, zależą od potencjału aktora, którego działania mają być kształtowane. Dlatego autor postuluje rozróżnianie źródeł siły i możliwości jej użycia. Te same instrumenty gospodarcze mogą być skuteczne w powodowaniu zachowań pożądanych jednego państwa, nie zadziałają natomiast w przypadku innego aktora. D. A. Baldwin nie zgadza się również z poglądem, że wzrost siły jednego państwa może się dokonać tylko kosztem drugiego. Wykazuje, że szczególnie wzajemne wpływy gospodarcze mogą się przyczynić do wzrostu siły partnerów handlowych ${ }^{69}$.

Problemem współzależności polityki wewnętrznej i zagranicznej zajął się Peter Gourevitch. Uznając wpływ sytuacji w poszczególnych państwach na system międzynarodowy, zaproponował badanie wpływu odwrotnego: sytuacji międzynarodowej na politykę wewnętrzną. Podając wiele przykładów wzajemnego oddziaływania na wielu polach, postulował uwzględnianie obu czynników w analizach zarówno polityki wewnętrznej, jak i zagranicznej ${ }^{70}$.

68 Ibidem, s. 206.

69 Ibidem, s. 21-24.

70 P. Gourevitch, The Second Image Reversed: the International Sources of Domestic Politics, „International Organization”, Autumn 1978, s. 881-912. Na ten temat zob. także: P. J. Katzenstein, International Relations and Domestic Structure: Foreign Economic Policies of Advanced Industrial States, „International Organization”, Winter 1976, s. 2-45. 
Badacze MEP widzieli konieczność zintegrowanej analizy polityki wewnętrznej i zagranicznej państw. David Baldwin i Robert Kay zauważyli, że struktura międzynarodowych stosunków wpływa na zdolność przywódców państw do utrzymania władzy. Autorzy podkreślali, że dotyczy to zarówno stosunków politycznych, jak i gospodarczych. D. A. Baldwin i R. Kay stwierdzili, że działania grup interesów stanowią poważne zagrożenie dla wolności handlu, w związku z czym rządy muszą interweniować i szukać kompromisowych rozwiązań, gdyż koszty wprowadzenia środków doraźnych mogą być szkodliwe dla gospodarki narodowej w dłuższym okresie. Mogło to prowadzić do powstawania protekcjonistycznych bloków handlowych ${ }^{71}$.

Ciekawą teorię związków polityki z gospodarką przedstawił David Calleo. Według niego, każde nowoczesne państwo narodowe jest złożone ze skomplikowanego systemu grup interesów, ideologii i instytucji. Jego stabilność opiera się na konsensusie tych wszystkich czynników, który jest bardzo kruchy. Takie zasady rządzą nie tylko relacjami politycznymi, ale także gospodarką i stosunkami społecznymi. „Każdy model, który nie bierze pod uwagę politycznych uwarunkowań w państwach narodowych i zdania obywateli, nie ma nic wspólnego ze współczesną rzeczywistością" - przekonywał D. Calleo ${ }^{72}$. Jednak to rządy podejmują ostateczne decyzje. To prowadzi do sytuacji, kiedy każda nowoczesna gospodarka jest ,zainfekowana” polityką (ang. every economy is political economy). Jego zdaniem, państwa są skłonne brać udział w systemie międzynarodowych porozumień i organizacjach, dopóki nie będzie to zakłócało równowagi między interesami grup istniejących $\mathrm{w}$ jego obrębie i będzie przynosiło wymierne korzyści ${ }^{73}$. Według Davida Calleo wszystkie teorie zakładające małą lub zanikającą rolę państwa narodowego, nie mogą być pomocne w zrozumieniu stosunków międzynarodowych.

Wyodrębniająca się na początku lat siedemdziesiątych XX wieku subdyscyplina nauki o stosunkach międzynarodowych - MEP, powstawała w oparciu o obserwacje dynamicznych zmian w gospodarce światowej. Od tamtej pory obserwujemy jej nieustanny rozwój. Formułowane są nowe teorie, uwzględniające interakcje między czynnikami politycznymi i gospodarczymi na arenie międzynarodowej. Dostrzegano różnorodność i złożoność tych wpływów, biorąc pod uwagę nie tylko zmienność sytuacji politycznej i ekonomicznej na świecie, ale także procesy wewnętrzne w obrębie państw narodowych i ich postrzeganie przez obywateli. Podważano nadrzędność państw w stosunkach międzynarodowych, wskazując na nowych aktorów. Współcześnie niezwykle rzadko powstają publikacje naukowe z tej dziedziny, skupiające się jedynie na relacjach politycznych, nie biorące pod uwagę uwarunkowań gospodarczych.

71 D. A Baldwin, R. E. Kay, International Trade and International Relations, w: World Politics and International Economics, op. cit., s. 130.

72 D. P. Calleo, American Foreign Policy and American European Studies: An Imperil Bias?, w: The United States and Western Europe. Political, Economic and Strategic Perspectives, ed. W. F. Hanrieder, Cambridge (Massachusetts) 1974, s. 76.

73 Ibidem, s. 60. 
Niewątpliwie w dobie globalizacji wzrosła również świadomość społeczna o współzależności tych dwóch aspektów.

\title{
STRESZCZENIE
}

Artykuł dotyczy międzynarodowej ekonomi politycznej (MEP) jako subdyscypliny stosunków międzynarodowych, badającej wpływ decyzji politycznych na gospodarkę oraz sytuacji ekonomicznej na działania polityczne. Opisana jest geneza wyodrębnienia się MEP w latach 70 . XX w., kiedy z powodu zasadniczych zmian w gospodarce światowej zaczęto zauważać w większym stopniu wpływ tych zjawisk na relacje międzynarodowe i politykę poszczególnych państw. Powstawały wtedy pionierskie prace nie tylko teoretyczne, ale również opisujące stosunki między państwami z nowej perspektywy. Zaprezentowane zostały również obszary badawcze MEP oraz metodologia. W kolejnej części przedstawione są pierwsze teorie MEP: merkantylizm (definiowany także jako neomerkantylizm lub nacjonalizm gospodarczy), liberalizm i strukturalizm, a także nowe teorie, związane z podejściem ekologicznym, krytyką feministyczną czy nurtem postmodernistycznym. Zostały również zanalizowane koncepcje dotyczące uwarunkowań ekonomicznych polityki zagranicznej i wewnętrznej państw narodowych.

\section{CONNECTIONS BETWEEN POLITICS AND ECONOMY IN INTERNATIONAL RELATIONS RESEARCH}

\begin{abstract}
The objective of this article is to present the development of the International Political Economy (IPE) as the sub-discipline of the international relations. It deals with the influence of political decisions on the economy, and the economic situation on the political activities of the states. The genesis of the IPE can be traced in the 1970s. when the major changes in the world economy occurred. The greater attention was paid to the impact of those events on the international relations and the policy of particular states. The pioneer books were published then: theoretical ones and the works which presented the international relation from a new perspective. The article includes also the basic definitions, the scope of the research as well as the methodology applied in the IPE. The theories (based on mercantilism, liberalism and structuralism) and the new approaches: ecological, feminist critique etc. are also presented. In the last part of the text the concepts of the role of the economic factor in foreign and domestic policy of the nation states are analyzed.
\end{abstract}

